\title{
Overdue Policies:
}

\section{A Comparison of Alternatives}

\begin{abstract}
Most library literature assumes that devices such as library fines and overdue notices are integral to the maintenance of book circulation. This study measures and compares the effects on book return rates when three different types of deterrent methods are applied in recovering books in a university library. The three methods examined include overdue notices and threat of encumbrance; overdue notices only; and no notification.
\end{abstract}

\section{BACKGROUND}

O VERDUE NOTICES ARE ASSUMED a necessary part of library circulation. Howell reports that college librarians seem so firmly committed to the routine of sending frequent overdue notices that it is easy to accept this practice as an integral part of good library service. ${ }^{1}$ The effectiveness of overdue notices in eliciting prompt return of library materials is rarely questioned in library circles. However, a search of library literature produces scant statistical data to support this assumption.

Available data are not concerned with the validity of the overdue notice itself, but with its application regarding timing, frequency, fines, etc. The professional literature does not consider the effectiveness of overdue notices per se. In contrast, a great deal of information is available on the subject of fines and their implications. Classed with fines as a common deterrent method is the encumbrance system; yet, little mention is

The authors are staff members of the Instructional Media Research Unit, Libraries and Audio-Visual Center, Purdue University, West Lafayette, Indiana. made of encumbrance policies and their effectiveness in studies of threats of deterrence. Although differences do exist in the two deterrent methods, their similarities in philosophy allow for similar study applications.

With few exceptions, the trend in libraries is to abolish fines. ${ }^{2}$ Yet both sides of the fines controversy claim improved book return rates with their respective policies. Howard reports that the suspension of fines in Vigo County (Indiana) Library improved public relations, while the library experienced an increase in lending and a decrease in losses. ${ }^{3} \mathrm{~A}$ review of the literature reveals that several librarians have reported successful results from the suspension of fines, e.g., Windsor (Ontario) Public Library claimed overdues substantially reduced with the suspension of fines. From the 18,533 first notices sent, only 2,924 follow-ups were necessary. ${ }^{4} \mathrm{~A}$ later progress report from Windsor indicated that their first report had been overly optimistic, but they continued to support the basic findings of fewer overdue books following the cessation of fines. ${ }^{5}$

On the other hand, Tootell disagrees, stating that although fines should never be used for income, their use is justified 
to insure prompt return of books. ${ }^{6}$ To support his statement, Tootell cites a 75 percent cut in overdue problems after implementation of a fine system. Thus far, the studies cited in reference to deterrence systems have been related to the library sciences. A cursory search of the fields of criminology and psychology resulted in only one pertinent study. The research of Chambliss on university parking violators supports the deterrence theory behind the encumbrance system. ${ }^{7}$ In his study, it was found that when parking meter violations were strictly enforced, the number of frequent offenders decreased significantly. Although this research in particular reinforces the possibility that threat may serve as a viable deterrent for some offenses, questions still remain because so little evidence is available concerning the effects of overdue notices or the threat of encumbrance.

\section{Problem}

Taking a circulation overdue policy, a measurement and comparison were made among selected variations or levels of that policy. Three levels were judged critical in setting circulation overdue policies, and methods were devised to study them. The three levels of the overdue policy factor were identified and categorized as: Group A, overdue notices and threat of encumbrance; Group B, overdue notices and no threat of encumbrance; and Group C, no overdue notices and no threat of encumbrance. (For purposes of this study, encumbrance was a temporary holding of students' records so that they would be unable to register or receive a transcript of grades until such time as their library records were cleared.)

Answers were sought to four basic questions. What are the effects of nonnotification of overdue books? Is the percentage of return for overdue books significantly increased by the distribution of overdue notices and threats of encumbrance? Is the percentage of return for overdue books significantly affected by the receipt of a threat of encumbrance? What effect does an overdue notice and threat of encumbrance have on the rate of book return over time? Because the research evidence did not indicate which policy produced the highest percentage of return for overdue books, the hypotheses for this study, as shown, had no directional prediction.

1. Twenty-eight-day observation: There will be no significant difference in percentage of return for subjects ( $\mathrm{Ss}$ ) tested under three different treatment conditions: (A) overdue notices and threat of encumbrance, (B) overdue notices only, and (C) no notification, when observed twenty-eight days after checkout.

2. Thirty-five-day observation: There will be no significant difference in percentage of return for Ss tested under three different treatment conditions: (A) overdue notices and threat of encumbrance, (B) overdue notices only, and (C) no notification, when observed thirtyfive days after checkout.

\section{Experimental Design and Procedures}

The method selected for testing the hypotheses is described by Campbell and Stanley as a pretest-posttest-delayed post true experimental design. ${ }^{8}$ Using their graphic symbols, the design model took the following form:

$\begin{array}{lllll}\mathrm{R} & \mathrm{O}_{1} & \mathrm{X}_{\mathrm{a}} & \mathrm{O}_{2} & \mathrm{O}_{3} \\ \mathrm{R} & \mathrm{O}_{4} & \mathrm{X}_{\mathrm{b}} & \mathrm{O}_{5} & \mathrm{O}_{6} \\ \mathrm{R} & \mathrm{O}_{7} & \mathrm{X}_{\mathrm{c}} & \mathrm{O}_{8} & \mathrm{O}_{9}\end{array}$

The symbol $\mathrm{R}$ indicates that each book checkout or transaction was randomly assigned to either treatment group A, B, or $\mathrm{C}$ and that an observation had been made. Observations of the percentage of books returned, namely, $\mathrm{O}_{1}, \mathrm{O}_{4}$, and $\mathrm{O}_{7}$, were made twenty-two days after 
checkout. The twenty-two-day observations fell one day after all books were due for the three treatment groups. These observations were essentially premeasures in that no treatment conditions had been instituted at this time. Postmeasures, or observations $\mathrm{O}_{2}, \mathrm{O}_{5}$, and $\mathrm{O}_{8}$, examined the percentage of books returned twenty-eight days after checkout, or one week after all books were due for these three groups. By this time all treatment conditions had been instituted at least six days before these observations were made. Delayed postmeasures, or observations $\mathrm{O}_{3}, \mathrm{O}_{6}$, and $\mathrm{O}_{9}$, examined the percentage of books returned thirty-five days after checkout, or two weeks after all books were due for these three groups. Again, all treatment conditions had been instituted, in this case thirteen days before these final observations were made. The symbol X indicates an experimental or treatment variable. In the above design model, the variable $X_{a}$ (Group $A$ ) represents those subjects (Ss) with overdue books who received an overdue notice card and threat of encumbrance; $X_{b}$ (Group B) represents those Ss with overdue books who received an overdue notice, but no threat of encumbrance; $X_{\mathbf{c}}$ (Group $C$ ) represents those Ss with overdue books who received no notice of any kind.

Figure 1 further illustrates the design and specifies the number of $S$ s included in each group for each of the six observations. (For purposes of this study, it was assumed that each book checkout or transaction would represent a unique individual $S$ assigned to a given group. However, when an individual $S$ checked out more than one book at a time, all transactions for that $S$ were randomly assigned to one of the three groups.) It can be seen under the twenty-two-day observation that originally a total of 969 Ss who checked out books were assigned to Group A, Group B was assigned 1,524 Ss, and Group C received $1,868 \mathrm{Ss}$. Also listed are the number of Ss who had not returned books after twenty-eight days (i.e., one week after date due) and the number of Ss who had not returned books after thirty-five days (i.e., two weeks after due date).

With the cooperation and help of the staff of the Purdue University General Library, a three-week time period was
22-Day Observation

Includes total $S$ s assigned to each group; the percentage of return up to date due was observed and compared for each group.
28-Day Observation

Includes Ss who had not returned books after 22 days; the percentage of return up to 28 days after checkout was observed and compared for each group.
35-Day Observation Includes Ss who had not returned books after 28 days; the percentage of return up to 35 days after checkout was observed and compared for each group.

\begin{tabular}{lccc}
\hline $\begin{array}{l}\text { Group A } \\
\text { (overdue notice and } \\
\text { threat of encum- } \\
\text { brance) }\end{array}$ & 969 & 322 & 114 \\
\hline $\begin{array}{l}\text { Group B } \\
\text { (overdue notice only) }\end{array}$ & 1,524 & 523 & 233 \\
\hline $\begin{array}{l}\text { Group C } \\
\text { (no overdue notice } \\
\text { or threat of encum- } \\
\text { brance) }\end{array}$ & 1,868 & & \\
\hline
\end{tabular}

Fig. 1

Study Design 
selected for data collection, and arrangements were completed for running the study. All patrons who checked out General Library materials for the standard twenty-one-day loan period would serve as Ss. Upon arrival at the circulation desk with materials for checkout, each of the $\mathrm{Ss}$ was randomly assigned to one of the three study conditions. This was handled discreetly by the special numbering and lettering system found on each of the transaction cards.

As briefly mentioned earlier, the procedures progressed in the following manner. Two days after each due date, Ss in Group A were sent an overdue notice which listed the author, title, call number, and transaction number of each book. Students received a printed notice indicating the General Library renewals telephone number and a warning of possible encumbrance if the books were not returned. Faculty and other users were included in this group; however, they did not receive a threat of encumbrance. (Eventually for students in Group A, encumbrance proceedings were initiated in the traditional manner three to four weeks after the due date.) Group B Ss received the overdue notices including author, title, call number, transaction number, and the General Library renewals telephone number; however, no threat of encumbrance was enclosed. Group C Ss were not sent overdue notices during the study period.

Data for the three groups were tallied on a daily basis. This provided a record of the number of books checked out per day for each group, the number of books not returned by the date, and the number of books remaining on each successive day.

\section{REsUlts}

The analysis of variance tests (using a single-factor analysis as described by Winer ${ }^{9}$ ) for the twenty-eight-day and thirty-five-day observation periods are presented in summary Tables 1 and 2 . As can be seen in Tables 1 and 2, significant differences were found. Once a significant overall $\mathrm{F}$ is achieved, it is accepted practice to examine the group means (in this case the percentage of books returned) to find the reason for these effects and to attempt to interpret their meaning. This is termed a post-hoc comparison and is used to evaluate any trends among means. There are several methods available for testing the signifcance of post-hoc comparisons. For purposes of this study, it was decided that if an overall significant $\mathrm{F}$ test were achieved, differences between treatment means would be probed by the Newman-Keuls method.

TABLE 1

Three-Group ANalysis of Varlance for Comparison of Return Rate Twenty-eight DAYS AFTER CHEckout

\begin{tabular}{lrrrr}
\hline \hline \multicolumn{1}{c}{$\begin{array}{c}\text { Source of } \\
\text { Variation }\end{array}$} & $\begin{array}{c}\text { Mean } \\
\text { Squares }\end{array}$ & df & F-Ratio & P \\
\hline $\begin{array}{l}\text { Between groups } \\
\text { Within groups }\end{array}$ & .23528 & 2 & $45.763^{\circ}$ & .0000 \\
Total & .2499 & 1427 & & \\
\hline
\end{tabular}

- Significant beyond the .01 level (Winer, Statistical Principles, p.646-47).

TABLE 2

Three-Group Analysis of Variance for Comparison of Return RATE ThirTy-FIVE Days after Checkout

\begin{tabular}{lrrrr}
\hline \multicolumn{1}{c}{$\begin{array}{c}\text { Source of } \\
\text { Variation }\end{array}$} & $\begin{array}{c}\text { Mean } \\
\text { Squares }\end{array}$ & df & F-Ratio & P \\
\hline Between groups & 1.1805 & 2 & $5.165^{\circ}$ & .0062 \\
Within groups & .2286 & 727 & & \\
Total & .2312 & 729 & & \\
\hline
\end{tabular}

- Significant beyond the .01 level (Winer, Statistical Principles, p.646-47).

The first hypothesis tested differences across all three groups twenty-eight days after books were checked out. The analysis of variance of the data for these three groups, as illustrated in Table 1 , revealed an overall significant difference between the means. Further, the Newman-Keuls test indicated that all 
pairs of means were significantly different at the .05 level. The data revealed that $S$ s in Group A (overdue notice and threat of encumbrance) had a significantly higher return rate than $\mathrm{Ss}$ in Group C (no overdue notice and no threat of encumbrance). Also, Ss in Group B (overdue notice only) had a significantly higher return rate than Ss in Group C (no overdue notice and no threat of encumbrance). However, no significant difference in return rate was found between Ss in Group A (overdue notice and threat of encumbrance) and Ss in Group B (overdue notice only).

Figure 2 displays the book return rate for $S s$ in each of the three treatment groups. At least 60 percent of the books

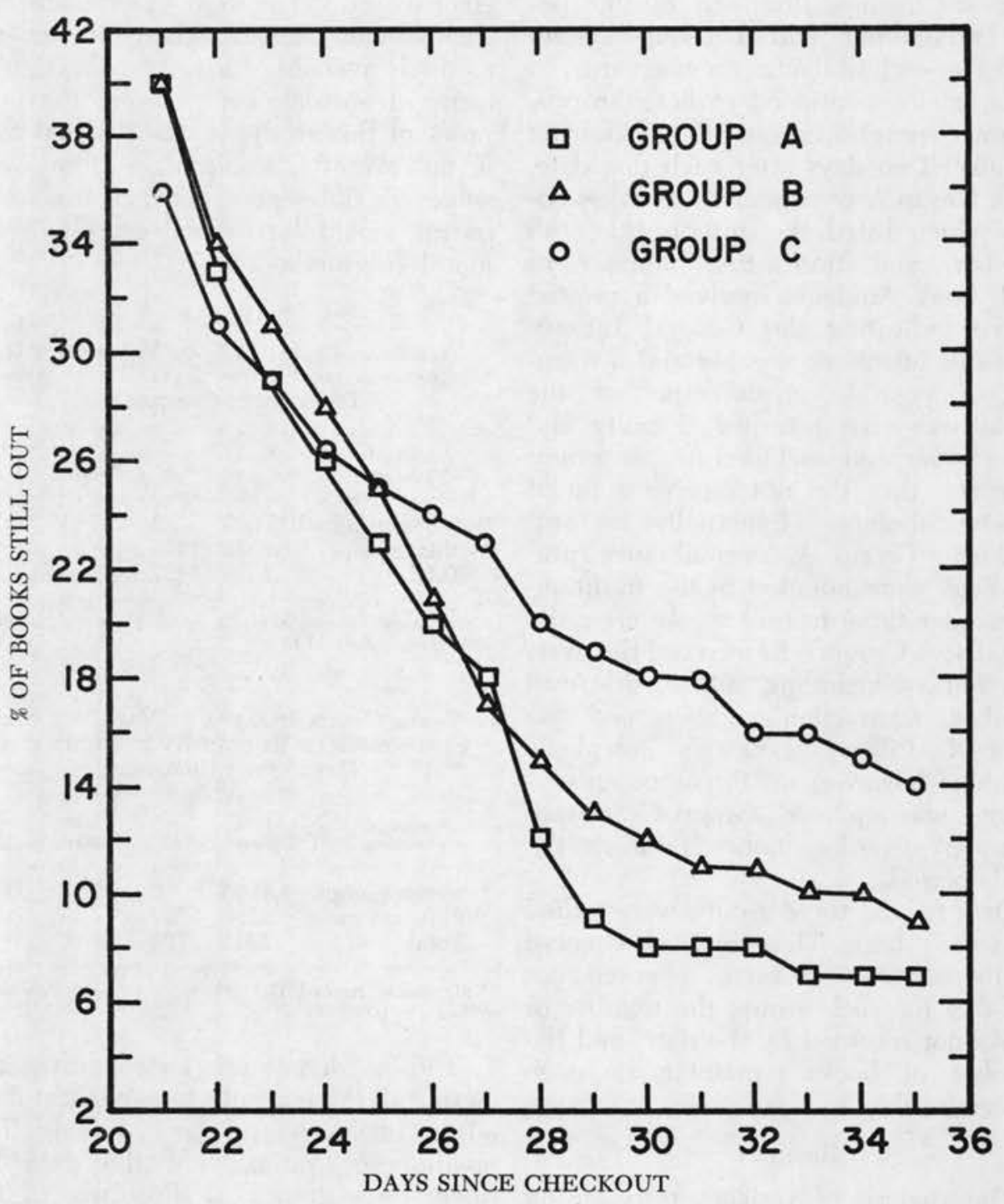

Fig. 2

Overdue Book Return Rate 
had been returned by the twenty-first day, i.e., the date due. Overdue notices were in the mail on the twenty-fourth day, and in most instances received on the twenty-fifth or twenty-sixth day. Marked differences are illustrated in book return rate for the three treatment groups once overdue notices were received in Groups A and B. These differences are particularly apparent from the twenty-sixth through the thirty-fifth day after checkout.

\section{ConCLusion}

The investigation pursued in this study supports the value of overdue notices. They appear to have an important reminder effect and improve the return rate of overdue books. Thus, under current conditions, an overdue policy seems preferable from the standpoint of book availability and improved service to users. The threat of encumbrance is effective in urging students to return library materials near the due date. Although the effect of the encumbrance threat diminishes several days after the receipt of the overdue notice, the encumbrance system does not appear to have the cumulative and deterring effect of a fine system. Users are not deterred from returning long-overdue books as they might be under a fine system where costs to users accumulate over time.

Libraries interested in examining the effects of variant overdue policies in their own libraries could do so by replicating the data collection and analysis described above. Even an inspection of the raw data itself would yield book return trends that would provide guidance in the reconsideration of overdue policies.

\section{REFERENCES}

1. Everett Howell, "Overdues in CollegeWhose Responsibility?" Library Journal 86: 19 (Nov. 1, 1971).

2. "Another Library Eliminates Fines," Wilson Library Bulletin 44:16 (Sept. 1969).

3. Edward N. Howard, "Breaking the Fine Barrier," ALA Bulletin 63:1541-45 (Dec. 1969).

4. "Ontario 'No-Fine' Policy Rated a Success by Library," Library Journal 97:2028-31 (June 1, 1972).

5. "Windsor's 'No-Fine' Policy: Progress Report from Ontario," Library Journal 98:1077 (April 1, 1973).

6. L. G. Tootell, "Quickies," New Library
World 73:284 (May 1972).

7. William J. Chambliss, "The Deterrent Influence of Punishment," in Stanley E. Grupp, ed., Theories of Punishment (Bloomington: Indiana Univ. Pr., 1971). Reprinted from Crime and Delinquency 12:70-75 (Jan. 1966).

8. Donald T. Campbell and Julian C. Stanley, Experimental and Quasi-Experimental Designs for Research (Chicago: Rand McNally \& Company, 1963), p.13.

9. B. J. Winer, Statistical Principles in Experimental Design (New York: McGraw-Hill, 1962). 